\title{
Handbook of Florida Water Regulation: Food Quality Protection Act ${ }^{1}$
}

\author{
Michael T. Olexa, Luke D'Isernia, Laura Minton, Dulcy Miller, and Sarah Corbett ${ }^{2}$
}

\section{Preface}

This handbook is designed to provide an accurate, current, and authoritative summary of the principle Federal and Florida laws that directly or indirectly relate to agriculture. This handbook should provide a basic overview of the many rights and responsibilities that farmers and farmland owners have under both Federal and Florida laws as well as the appropriate contact information to obtain more detailed information. However, the reader should be aware that because the laws, administrative rulings, and court decisions on which this handbook is based are subject to constant revision, portions of this publication could become outdated at anytime.

Several details of cited laws are also left out due to space limitations.

This handbook is distributed with the understanding that the authors are not engaged in rendering legal or other professional advice, and the information contained herein should not be regarded as a substitute for professional advice. This handbook is not all inclusive in providing information to achieve compliance with the Federal and Florida laws and regulations governing water protection. For these reasons, the use of these materials by any person constitutes an agreement to hold harmless the authors, the Florida Cooperative Extension Service, the Institute of Food and Agricultural Sciences, and the University of Florida for any liability claims, damages, or expenses that may be incurred by any person as a result of reference to or reliance on the information contained in this handbook.

\section{Overview}

In 1996, the Food Quality Protection Act (FQPA) amended FIFRA with respect to the EPA's process of establishing tolerances (the amount of pesticide residue that can be legally present in/on food) for pesticide residues in food and in the atmosphere. The primary purpose of FQPA is to protect the public from the health risks presented with exposure to excessive pesticide residues, in/on foods and in the everyday surroundings such as in the home and at work.

1. This is EDIS document FE589, a publication of the Food and Resource Economics Department, Florida Cooperative Extension Service, Institute of Food and Agricultural Sciences, University of Florida, Gainesville, FL. Published December 2005. Please visit the EDIS website at http://edis.ifas.ufl.edu.

2. Michael T. Olexa, Professor, Food and Resource Economics Department, Florida Cooperative Extension Service, Institute of Food and Agricultural Sciences, University of Florida, Gainesville, FL; Director, Agricultural Law Center, University of Florida, Gainesville, FL; and Chair, Agricultural Law Committee of The Florida Bar. Luke D'Isernia, former student (graduated cum laude in 2005), Levin College of Law, University of Florida, Gainesville, FL. Laura Minton, Attorney, Dean, Mead, Egerton, Bloodworth, Capouano, and Bozarth, Orlando, FL. Dulcy Miller, attorney, Foley and Lardner, LLP, Orlando, FL. Sarah Corbett, Attorney, Florida Second District Court of Appeal, Lakeland, FL.

The Institute of Food and Agricultural Sciences (IFAS) is an Equal Opportunity Institution authorized to provide research, educational information and other services only to individuals and institutions that function with non-discrimination with respect to race, creed, color, religion, age, disability, sex, sexual orientation, marital status, national origin, political opinions or affiliations. U.S. Department of Agriculture, Cooperative Extension Service, University of Florida, IFAS, Florida A. \& M. University Cooperative Extension Program, and Boards of County Commissioners Cooperating. Larry Arrington, Dean 


\section{Why Is FQPA Significant?}

FQPA represents the single largest shift in federal pesticide policy and process ever undertaken. FQPA has profoundly changed the way pesticide tolerances are determined. Before FQPA, each pesticide was examined individually when setting a residue tolerance. Now the EPA must consider the collective effects of all pesticides that act in the same manner on human health. Also before FQPA, when setting residue tolerances the EPA only considered exposure to pesticides in food. Now the EPA must consider cumulative exposure through all possible sources, including drinking water. Furthermore, before FQPA, the EPA, in setting residue tolerances, added safety factors to account for animal testing and human unpredictability, creating a 100- to 1000 -fold safety margin. Now the EPA must consider infants and children in setting residue tolerances. An additional ten-fold safety factor may be added to protect infants and children, creating a 1,000- to 10,000-fold safety margin.

Provisions added to FIFRA by the enactment of FQPA include:

- A single health-based safety standard for pesticide residue tolerances in both raw and processed foods.

- An explicit determination that residue tolerances are safe for children.

- The requirement that all existing tolerances to be reassessed under the new standard.

- The EPA must review all existing residue tolerances within ten years.

\section{How Does FQPA Affect Farmers, Agricultural Landowners, and Other Pesticide Users?}

The changes that FQPA introduced into the EPA's determination of residue tolerances have limited the amount (different types) of pesticides that can be used for any particular purpose/situation. In order to add a new use to an existing pesticide or to add a new pesticide product to be used for a particular purpose/situation under FQPA's requirements, the pesticide manufacturer can either (1) make label or formulation changes so the pesticide is safer or (2) take away a pesticide and/or its use for a particular purpose/situation. This makes it very important for farmers, agricultural landowners, and other pesticide users to check the label on the pesticide container before they purchase and use a pesticide-no matter how familiar they are with the pesticide, how many years they have used the particular pesticide, or how many times they have purchased the particular pesticide. FIFRA requires strict compliance to the instructions printed on all pesticide labels. Pesticide labels are important because they have become a central tool of enforcing FIFRA and state laws (see the "What Is So Important about Pesticide Labels?" section of FE590). Failure to comply with the label can result in strict penalties, violations of FIFRA and CERCLA, and liability for CERCLA cleanup costs (see the CERCLA exemption and penatly sections of FE584, and the FIFRA labeling requirement and penanlty sections of FE588).

Also it is important to note that the farmer can be penalized even if an employee of the farmer was responsible for the failure to follow the label instructions.

For more information on FQPA, please contact the EPA.

\section{Source}

104 HR 1627; N.O. Nesheim, UF/IFAS

\section{Acknowledgments}

The authors are indebted to the personnel of both state and federal agencies who provided their time and advice in the preparation of this handbook. The authors are especially indebted to Richard Budell of the Office of Agricultural Water Policy of the Florida Department of Agriculture and Consumer Services for providing funds for the development of this publication. 